\title{
$18 \mathrm{Cr}$ ステンレス鋼の腐食試験*
}

浅田千秋**野崎善蔵** 椙山太郎**稲垣修一**

\section{Corrosion Testing for 18 Cr Stainless Steel}

Chiaki Asada, Zenzô Nozaki, Tarô Sugiyama and Shûichi Inagaki

For the purpose of finding the most suitable laboratory corrosion test to estimate the corrosion resistance of $18 \mathrm{Cr}$ stainless steel (SUS 24) strips under atmospheric circumstances, field test and laboratory tests, i. e. salt spray test, humidity test, dew-cycle corrosion test, thermographic corrosion test, and boiling nitric acid test $(6 \mathrm{hrs}$ and 48hrs) were applied to 12 kinds of $18 \mathrm{Cr}$ stainless steel strips. But the results of all the laboratory tests didn't coincide with the one of the field test. There were, however, a few kinds of strips that showed comparatively good (No. 2) or poor (No. 1) performance through all the tests.

\section{1. まえがき}

いわゆる $18 \mathrm{Cr}$ ステンレス鋼すなわち SUS 24 鋼帯の 大気暴露下の酎食性をいかなる促進試験法によって評価 すべきかという問題に関して基礎資料を得るために各種 の試料について各種の腐食試験方法の比較を行なった。 すなわちフェライト系ステンレス鋼 SUS 24 の鋼帯につ いて C, Cr の各\%を变化させあるいは $\mathrm{Ni}, \mathrm{Cu}, \mathrm{Mo}$, $\mathrm{Al}, \mathrm{Nb}, \mathrm{Be}$ 等を添加した 12 種類の供試材を実験的に 製作し，大気暴露試験を標準として 5 種類の腐食促進試 験を含む 6 種類の腐食試験を実施し, その結果を比較し た。

2. 実 験 方 法

2.1 供試材化学成分

表 1 亿示す。

2.2 試験片製作工程
高周波誘導炉溶解 $200 \mathrm{~kg}$ 丸型鋼塊 $\stackrel{\text { 分塊 }}{\longrightarrow} 90 \times 145 \times l$ 熱延 $\longrightarrow 4.0 \times 160 \times l \longrightarrow$ 暁鈍 $\left(900^{\circ} \mathrm{C} \times 25 \mathrm{hr} \longrightarrow\right.$ 师冷, 真 空) 酸洗, バフ研摩 (400 500番), JIS No. 40 仕上げ

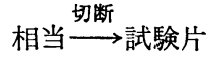

\section{$\mathbf{2 \cdot 3}$ 腐食試験方法}

JIS には SUS 24 を対象とする腐食試験法の規定がな いので, SUS 24 鋼帯の用途に近い各種の腐食環境を選 んで試験を実施した。表 $\mathbf{2}$ にこの研究に用いた腐食試験 の方法を記す。

\section{3. 実 験 結 果}

腐食試験結果を一括して図 1 亿示す。

湿潤試験 300 時間および発露腐食試験 200 時間の結果 試験片すべてに錆を生じなかった。

工業地帯において大気暴露試験を 4 力月間行なった結

表 1 供試材化学成分

\begin{tabular}{|c|c|c|c|c|c|c|c|c|c|c|c|c|c|}
\hline 合 番 & C & $\mathrm{Si}$ & $\mathrm{Mn} \mid$ & $P$ & $\mathrm{~S}$ & $\mathrm{Cu}$ & $\mathrm{Ni}$ & $\mathrm{Cr}$ & Mo & Al & $\mathrm{Nb}$ & $\mathrm{Be}$ & 特 \\
\hline 1 & .03 & $.30 \mid$ & .41 & .025 & .003 & .16 & .13 & 15.98 & .47 & & & & Mo \\
\hline 2 & .06 & .38 & .46 & .025 & .008 & .15 & .14 & 16.42 & & & & & 低 C \\
\hline 3 & $.07 \mid$ & .36 & .47 & .028 & .008 & .14 & .16 & 16.18 & & & .45 & & $\mathrm{Nb}$ \\
\hline 4 & .08 & .47 & .51 & .024 & .006 & .17 & .17 & 16.42 & & .45 & & & $\mathrm{Al}$ \\
\hline 5 & .05 & .37 & .51 & .024 & .010 & .73 & .16 & 16.42 & & & & & $\mathrm{Cu}$ \\
\hline 7 & .07 & .43 & .49 & .024 & .007 & .16 & .16 & 16.36 & & & & .012 & 低 Be \\
\hline 8 & $.07 \mid$ & .42 & .51 & .028 & .010 & .15 & .16 & 16.62 & & & & .023 & 高 Be \\
\hline 9 & .07 & .33 & .42 & .028 & .010 & .10 & .16 & 15.96 & & & & & 低 $\mathrm{Cr}$ \\
\hline 10 & .06 & .38 & .43 & .024 & .010 & .15 & .17 & 15.96 & & & & & 低 $\mathrm{C}$ 低 $\mathrm{Cr}$ \\
\hline 11 & .09 & .38 & .49 & .025 & .010 & .16 & .16 & 16.32 & & & & & 高 C \\
\hline 12 & .07 & .38 & $.47 \mid$ & .024 & .007 & .15 & .48 & 16.37 & & & & & $\mathrm{Ni}$ \\
\hline 13 & .08 & .38 & .42 & $.022 j$ & .007 & .15 & .14 & 17.43 & & & & & 高 $\mathrm{Cr}$ \\
\hline
\end{tabular}

* 略和 40 年 11 月 11 日 第 12 回富食防食討論会（名古屋）飞て発表

** 大同製銅(株)中央研究所 (名古屋市南区大同町 2 の 30 ) 
表 2 食試験方法

\begin{tabular}{|c|c|c|c|c|}
\hline No & 試酫 & 参考 規 格 & 留食評価方法 & 試 酫 法 \\
\hline 1 & 大気暴露試匼 & $\begin{array}{l}\text { JIS-K-5400-1959 } \\
\text { 「塗料一般試匼方法」 }\end{array}$ & $\begin{array}{l}\text { JIS-Z-2912-1959 } \\
\text { 「サビ登生度測定方法」 } \\
\text { による }\end{array}$ & 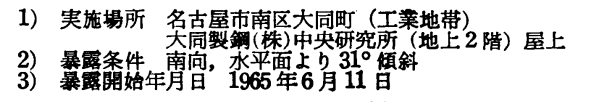 \\
\hline 2 & 塩水櫴霧試験 & $\begin{array}{l}\text { JIS-Z-2371-1955 } \\
\text { 「塩水噴霧試験方法」 }\end{array}$ & $\begin{array}{l}\text { JIS-Z-2912-1959 } \\
\text { 「甘ビ発生度測定方法」 } \\
\text { による }\end{array}$ & 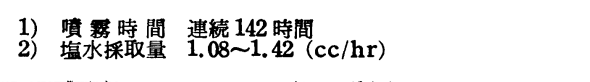 \\
\hline 3 & 発露度食試験*1 & 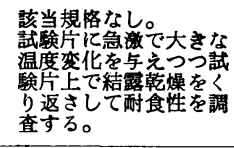 & $\begin{array}{l}\text { JIS-Z-2912-1959 } \\
\text { 「サビ発生度剧定方法」 } \\
\text { による }\end{array}$ & 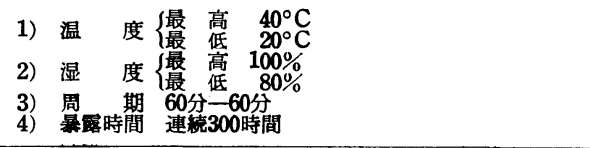 \\
\hline 4 & 湿潤試験 & $\begin{array}{l}\text { JIS-Z-0228-1960 } \\
\text { 「艺芷 } \times \text { 油湿閏試験 } \\
\text { 方法」 }\end{array}$ & $\begin{array}{l}\text { JIS-Z-2912-1959 } \\
\text { 「甘ビ発生度㨽定方法」 } \\
\text { による }\end{array}$ & 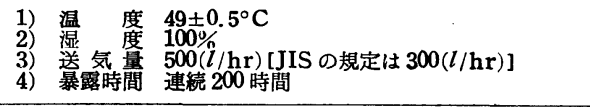 \\
\hline 5 & サーモグラフ試験*2 & 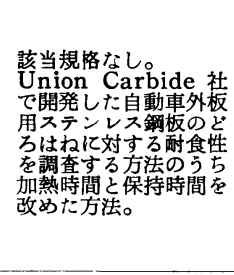 & $\begin{array}{l}\text { JIS-Z-2912-1959 } \\
\text { 「サビ発生度测定方法」 } \\
\text { による }\end{array}$ & 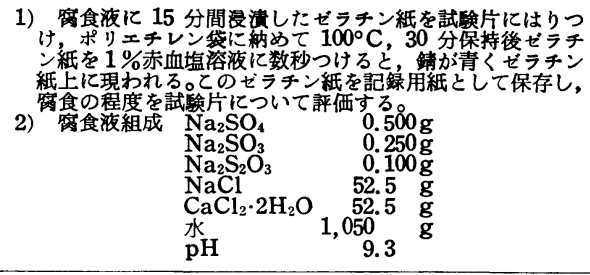 \\
\hline 6 & 沸膕硝酸試験 & 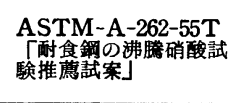 & 浻食速度 $\left(\mathrm{g} / \mathrm{m}^{2} \cdot \mathrm{hr}\right)$ & 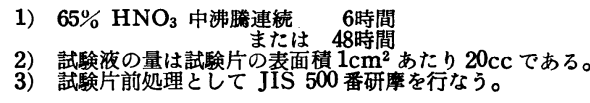 \\
\hline
\end{tabular}

*1 山崎式発露型零食試験機 D-100 型使用

${ }^{*} 2$ R. M. Fowler \& C. R. Bishop: Metal Progress, 88 90 (1963) Sept.

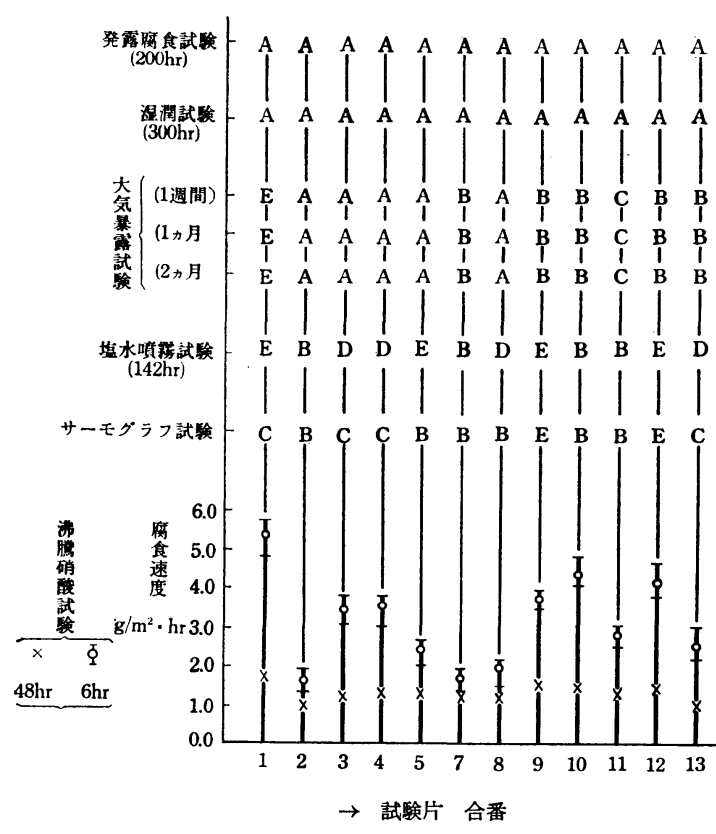

図 1 腐食試験結果

(困中フルファベットは JIS-Z-2912 に基づく等級を示す)

果, 錆発生度の等級は暴露期間にほとえど関係なく耐食 性の劣るものは 1 週間ですでに赤錆を多数生じた。また 等級に影響しない範囲内で錆の形状と数が評価の時期に よって変る場合があり， 1 週間後に認めた錆のうち 2 力
月後には消失するものがあった。錆発生度の測定は試験 片を石けん水を含ませたスポンジで軽くこすり洗ってか ら行なった。試験片の光沢は暴露 2 力月までではほとん ど変わらなかったが，4 月後には光沢が著しく減少し た。

塩水噴霧試験 142 時間後の試験片の外観を写真 1 に示 す。試験片の上端より下へ向って錆が縱に連なってい る。この錆を電解酸洗で除去したところ, 錆の下にはか なり深い腐食孔が認められた。このように錆が縦に連な る現象は, シャリング加工後試験に供した試験片および シャリング切ロをセーパー加工した試験の両者に見られ た。

サーモグラフ試験後の試験片の外観を写真 2 に示す。 この試験で生じた錆は円形であり，その形状は塩水噴霧 試験で生じた錆よりも大気暴露試験で生じた錆に近かっ た。

図 1 に示した沸騰硝酸試験の結果から明らかなよう に, いずれの試験片も加熱時間 6 時間の場合の方が48時 間の場合よりも腐食速度が大きく，かつ試験片合番間の 差が比較的明瞭であった。

\section{4. 実験結果の考察}

本研究の主なる目的は SUS 24 鋼帯の耐食性をいかな る試験法によって評価すべきかという問題に答えること にある。すなわち, 最も実用状態に近い大気暴露試験の 


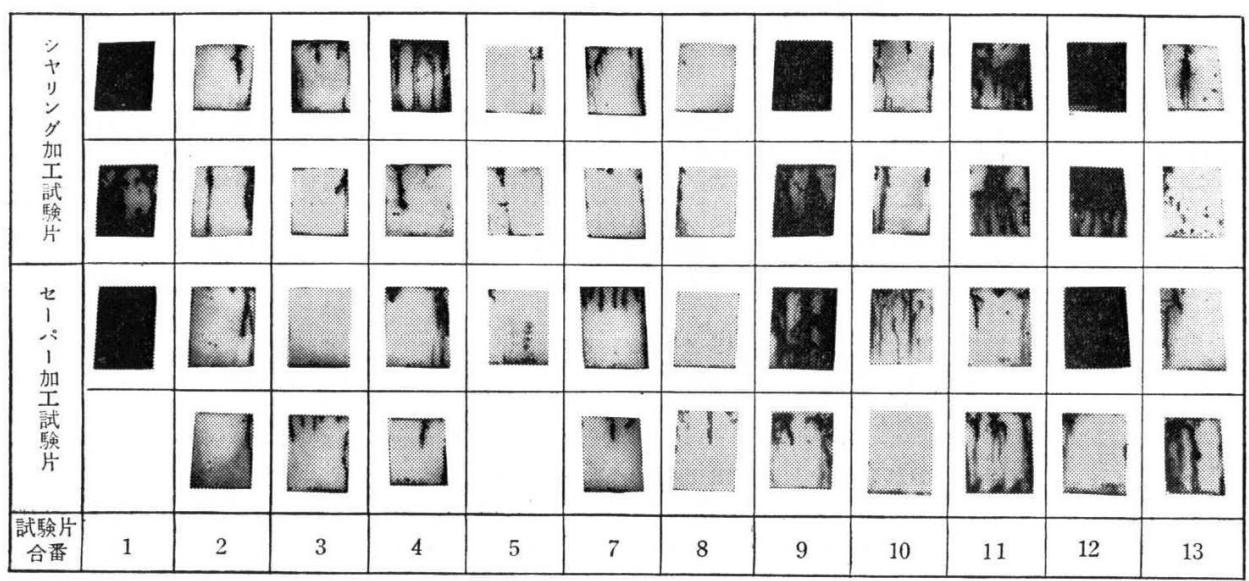

写真 1 塩水噴蓩試験連続 142 時間の結果

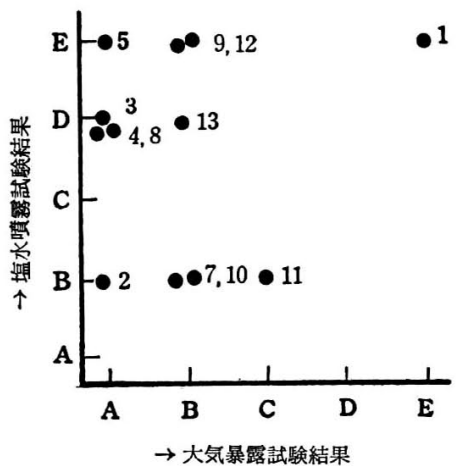

（1）大気暴露試験結果之塩水噴霧試験結果 との関䋆

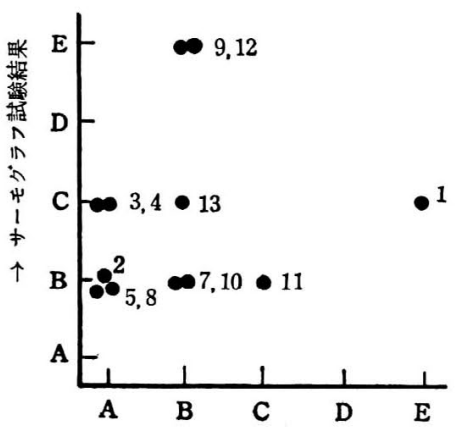

$\rightarrow$ 大気暴露試験結果

（4）大気暴露試験結果とサーモグラフ 武験結果との関係

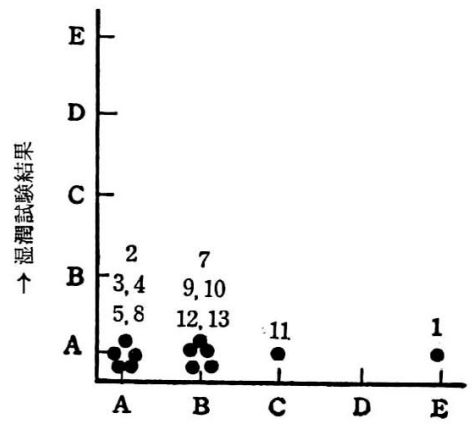

$\rightarrow$ 大気暴露試験結果

（2）大気暴露試験結果と湿潤試験結果 との関係

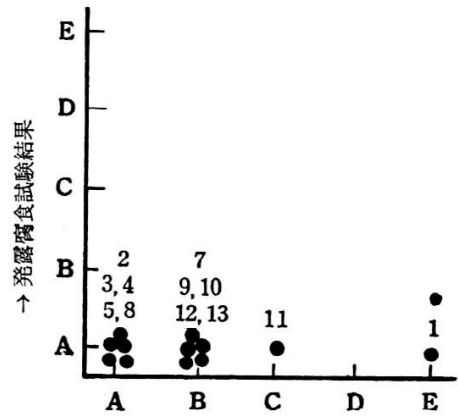

$\rightarrow$ 大気暴露武験結果

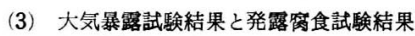
との関係

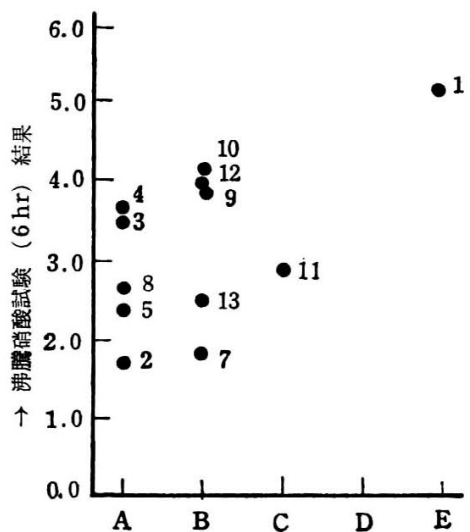

$\rightarrow$ 大気暴露試験結果

(5) 大気暴露試験結果之沸腃硝酸武験 $(6 \mathrm{hr})$ 結果との関倸

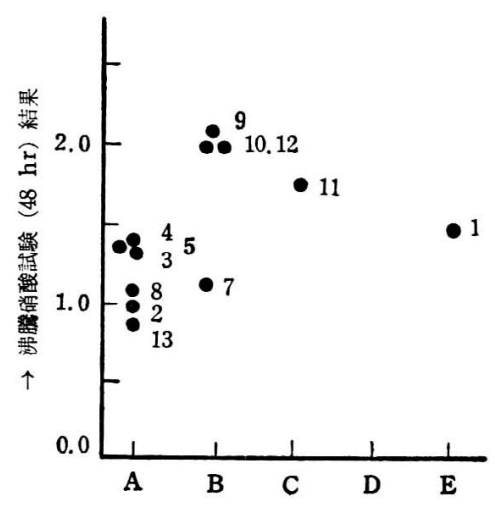

$\rightarrow$ 大気暴露試験結果

（6）大気暴露試験結果と沸腾硝酸試験 $(48 \mathrm{hr})$ 結果との関棌

図 2 大気暴露試験 2 力月の結果と各種促進試験結果との関俰

図中の数字は武験片の合番を示し,アルファベットは錆発生度の等䑥（JIS-Z-2912）を示す。 沸搃硝酸試験結果は简食速度 $\left(\mathrm{g} / \mathrm{m}^{2} \cdot \mathrm{hr}\right)$ で示す。 


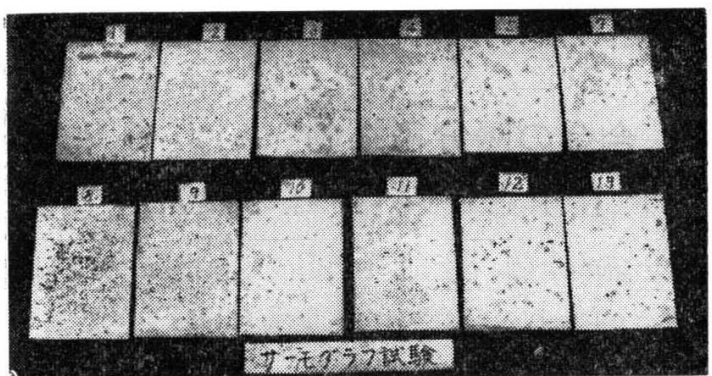

写真 2 サーモグラフ試験の結果

結果を腐食促進試験で推定しうることを期待して塩水獖 霧試験, 湿潤試験, 発露腐食試験, サーモグラフ試験沶 よび沸騰硝酸試験を実施した。以上の各々の促進試験で 得た結果と大気暴露試験結果との関係を図 2 亿示す。

塩水賲霧試験 142 時間の結果の等級注大気暴露試験の 結果よりも悪いことから塩水噴霧試験は大気暴露 2 力月 間よりも過酷な腐食条件を有するといえるが，この両者 の試験結果の間に相関は認められない。

湿潤試験 200 時間および発露腐食試験 300 時間の結果 注前述したように全然錆を生じなかったので，当然大気 暴露試験結果との間に相関は認められない。このことか ら，湿潤試験および発露腐食試験はこのままでは促進試 験とはなり得ず，促進試験として使用するためには適当 な腐食性ガスを導入することが望ましい。

サーモグラフ試験の結果の等級は大父暴露試験の結果 より悪いことからこの試験は大気暴露 2 力月間の試験よ りも過酷な腐食条件を有するので塩水噴霧試験と同様に
促進試験となり得るが，しかしサーモグラフ試験の結果 と大気暴露試験の結果との間泪関は認められない。

沸騰硝酸試験（6時間）および (48時間) の結果と大 気暴露試駼結果との間にも明瞭な相関は認められない。

以上の事がらより SUS 24 鋼带の大気暴露下の耐食性 を推定しうる促進試験法を見出すこと沈かなり困難であ るということができる。しかしながらここで取りあげた 試験の範囲内では試験片 No. 2 注すべての試験法につ いて成績が比較的良好であり，No. 1 注比較的劣ってい た。

5. 結 論

1） SUS 24 鋼帯の大気暴露下の耐食性の評価に適乙 た促進試験法を見出す目的で，12 種類のSUS 24 鋼帯に 6 種類の腐食試験を実施した。

2) 大気暴露試験において，1週間（168時間）まて 汇錆を生ずる試験片があったにもかかわらず，湿潤試験 200 時間および発露腐食試験 300 時問の結果ではいずれ の試験片にも錆を生じなかった。

3）塩水噴霧試験 142 時間, サーモグラフ試験の結果 試験片に錆を生じた。しかし両者および沸騰硝酸試験 （6時間および 48 時間）の結果と大気暴露試験 2 力月の 結果との間に明瞭な相関は認められなかった。

4）乙かし，あらゆる試験を通じて比較的良好な成績 を示す試験片と，比較的劣る成績を示す試験片が少数な がら存在した。

（昭和 41 年 2 月 21 日受理）

\section{Glossary of Terms used in Maintenance Painting (14)}

\section{$\mathbf{N}$}

\section{NACE No. 1 White Metal Blast Cleaned Surface}

Finish-this finish is defined as a surface with a gray-white, uniform metallic color, slightly roughened to form a suitable anchor pattern for coatings; this surface shall be free of all oil, grease, dirt, visible mill scale, rust, corrosion products, oxides, paint, or any other foreign matter; the surface shall have a color characteristic of the abrasive media used; photographic or other visual standards of surface preparation may be used to further define the surface.

NACE No. 2 Near-White Blast Cleaned Surface
Finish-this finish is defined as one from which all oil, grease, dirt, mill scale, rust, corrosion products, oxides, paint or other foreign matter have been removed from the surface except for very light shadows, very slight streaks or slight discolorations; at least 95 percent of the surface shall have the appearance of a surface blast cleaned to a white metal surface finish and the remainder shall be limited to the light discoloration mentioned above; photographic or other visual standards of surface preparation may be used to modify or further define the surface.

Mater. Prot., 4, No.1, 73〜78 (1965) Jan. 